\author{
Katarzyna Lewandowska, Luiza Organek \\ Instytut Socjologii \\ Uniwersytet Warszawski
}

\title{
JĘZYK, WARTOŚCI, GRANICE. REWITALIZACJA JEZZYKA ETNICZNEGO W DOBIE GLOBALIZACJI - SYTUACJA SPOŁECZNOŚCI KASZUBSKIEJ
}

\section{Rewitalizacja języków mniejszości}

Przyjmując Appaduraỉowską tezę o idącej za globalizacją deterytorializacji i kryzysie państw narodowych, należy na nowo postawić pytanie o wspólnotę wartości łączących ze sobą zindywidualizowanych członków zbiorowości [Appadurai, 2005]. Słabnące definiowanie świata w kontekstach grupowych na rzecz odniesień jednostkowych zdaje się mieć znaczące konsekwencje szczególnie dla grup mniejszościowych, skoncentrowanych dotychczas na podtrzymywaniu swojej specyfiki, własnej etniczności.

Współcześnie, według rozmaitych teoretyków, etniczność ulega rozmyciu, a nieuchronności tego procesu upatruje się w postępującej zmianie społecznej skupionej na samostanowieniu indywidualnej jednostki o sobie. Zewnętrzne mechanizmy współdecydujące o identyfikacji i odpowiedzi na pytanie, „kim jestem”, są redukowane. W tych warunkach w wątpliwość podane zostaje znaczenie etniczności jako postawy konstrukcji refleksyjnych podmiotów tożsamościowych. Implikuje to pytanie o skuteczność (i/lub potrzebę) podtrzymywania grupowych identyfikacji etnicznych, które mimo zmieniających się warunków społecznych i prognoz unifikacji wzorów kulturowych, zachowują swoją specyfikę.

W obecnej polityce europejskiej duży akcent kładzie się na działania promujące wielokulturowość. Idea ta służy nie tylko do opisu zróżnicowania kulturowego i etnicznego społeczeństw, ale stara się wpływać na sposoby zarządzania tym zjawiskiem przez państwa narodowe. Podstawowym mechanizmem jest w tym przypadku administracja i procesy instytucjonalne [Kymlicka, 2012]. Jednym z obszarów, wokół którego koncentrują 
one swoje działania - przez wprowadzanie regulacji prawnych - jest różnorodność językowa.

Procesy globalizacyjne przyczyniają się do uprzywilejowania języków międzynarodowej komunikacji (m.in. języka angielskiego). W świetle ich wysokiego prestiżu, mikrojęzyki używane przez wąskie grono jednostek należących do grup etnicznych, tracą na znaczeniu. Zjawisko to występuje nie tylko na poziomie międzynarodowym, ale również wewnątrzpaństwowym. W tym wypadku to język większości (np. język polski w Polsce) niejako naturalnie pozostaje w uprzywilejowanej pozycji wobec języków grup etnicznych, etnolektów lub gwar.

Zauważenie hierarchiczności językowych relacji jest kluczowe dla zrozumienia sytuacji grup mniejszościowych. Dla wielu z nich to właśnie język etniczny stanowi podstawową wartość społeczności, pozwalając jej zachować własną odrębność i tożsamość. Utrzymać kulturową specyfikę w dobie unifikacji wzorów. Używanie lub rezygnacja $\mathrm{z}$ etnicznego kodu językowego wyznacza zatem granice kulturowe/etniczne [Barth, 2004]. Pozwala na etniczne manifestacje, dlatego tak ważne są działania na rzecz ochrony języków mniejszościowych.

W ostatnich latach można zaobserwować instytucjonalną rewitalizację mikrojęzyków. Zainteresowanie językowym zróżnicowaniem świata łączy się $\mathrm{z}$ ideą wielokulturowości. Z jednej strony brak dyskryminacji i asymilacji kulturowej, z drugiej dbałość o społeczne podstawy ma sprzyjać zachowaniu języków mniejszościowych. Istotność tych działań powodowana jest uznaniem języka za wartość bezpośrednio związaną z tożsamością grupy. Przyglądając się społeczeństwu polskiemu, warto zwrócić uwagę na specyficzną sytuację społeczności kaszubskiej, dla której język etniczny zdaje się stanowić element szczególnie istotny - „wartość rdzenną” [Smolicz, 1987].

Koncepcję „wartości rdzennej” zaproponował Jerzy Smolicz, opisując ją jako ,jeden z najbardziej podstawowych elementów kultury określonych społeczności", znaczący element identyfikacyjny grupy [Smolicz, 1987: 59]. Wartość rdzenna - jedna lub wiele - stanowią zatem o odrębności kulturowej danej społeczności. Dany element kultury staje się „rdzenny” dla grupy, gdy jej członkowie „odczuwają bezpośrednią więź między ich tożsamością grupową a tym, co uważają za najbardziej kluczowy i wyróżniający element ich kultury" [Smolicz, 1987: 60].

Cechy te można dostrzec w relacji między społecznością kaszubską a jej językiem etnicznym. Przyglądając się historii grupy widać, że rodzima mowa zawsze stanowiła wyróżnik Kaszubów, zakorzeniając ich we własnej regionalności. Istotność językowej odrębności i wynikających z niej beha- 
wioralnych manifestacji etnicznych powodowały, że kaszubska „wartość rdzenna" stała się dostrzegalna również dla osób spoza grupy. W ten sposób, jak zauważył Cezary Obracht-Prondzyński: „obserwując toczące się przez ponad 150 lat dyskusje wokół statusu językowego kaszubszczyzny, można stwierdzić, że właściwie były one zakamuflowaną formą sporu o to, kim są Kaszubi” [Obracht-Prondzyński, 2002: 322]. Rola języka kaszubskiego ma zatem istotny wymiar tożsamościowy i stanowi najbardziej podstawowy wyróżnik społeczności kaszubskiej.

Zgodnie z zaproponowaną przez Smolicza teorią „wartości rdzennych”, język kaszubski będzie tym, co pozwala Kaszubom utrzymać swoją kulturową odrębność [Synak, 1998: 177]. Tym, co wyzwala symboliczne granice, ale też kształtuje tożsamość członków etnicznej wspólnoty przez przekazywanie istotnych dla tej kultury elementów właśnie za pośrednictwem rodzimej mowy. $\mathrm{Z}$ tego powodu, z punktu widzenia interesu grupy, istotne powinno być nie tylko dbanie o zachowanie wartości rdzennej i przekazywanie jej kolejnym pokoleniom, ale również poszerzanie zakresu stosowalności języka kaszubskiego. Aby proces utrzymywania żywotności języka był skuteczny, warto podejmować działania, w których na „wartość rdzenną" oddziaływać będzie inny element kultury grupy - np. religijność. Brunon Synak, w swoich badaniach nad społecznością kaszubską wskazuje, że tym, co charakteryzuje Kaszubów jest ich wyjątkowa religijność [Synak, 1998]. Przywiązanie do sfery sacrum sugeruje również istotną rolę Kościoła katolickiego i jego wpływ na etniczność grupy. Tym samym wprowadzanie języka kaszubskiego do sfery sakralnej mogłoby być sposobem na podtrzymywanie wartości rdzennej Kaszubów.

W tym znaczeniu język kaszubski będzie spełniał dwie funkcje. Zachowując rangę „wartości rdzennej” zostanie wpleciony w sferę sacrum, co może istotnie podnieść jego status społeczny i poszerzyć zakres jego stosowania. Dodatkowo przyczyni się do wzmożenia etnicznej identyfikacji. Należy pamiętać również o tym, że „język” jako taki istnieje w społecznej interakcji. Nie jest tylko sposobem komunikowania. Stanowi nośnik symboli istotnych z punktu widzenia grupy, ponieważ „zawartość treściowa każdej kultury daje się wyrazić w jej języku” [Sapir, 1978: 37]. Jeśli więc religijność jest dla Kaszubów szczególnie ważna, jej zetnicyzowanie przez wprowadzenie języka kaszubskiego do sfery sacrum nie powinno być niczym zaskakującym.

Symboliczny wymiar stosowania języka kaszubskiego będzie się zatem wiązał z poczuciem społecznej solidarności Kaszubów. Tworzony przez nich system społeczny, działający na wspólnym kodzie komunikacyjnym, 
zdaje się być wzmacniany również zewnętrznie - poprzez oficjalną instytucjonalizację kaszubskiej „rodzimej mowy”.

\section{Polityka językowa: instytucjonalna rewitalizacja języka kaszubskiego}

Kaszubi to jedyna grupa w Polsce, której odrębność językowa została uznana za język regionalny. Status „społeczności posługującej się językiem regionalnym" określa przyjęta w 2005 roku ustawa o mniejszościach narodowych i etnicznych oraz o języku regionalnym [Ustawa..., 2005]. Zgodnie z zapisami dokumentu, Kaszubi - nie będąc instytucjonalną mniejszością, lecz grupą odznaczającą się własnym językiem - mają prawa do stosowalności swojej mowy w sferze publicznej. Dotyczy to m.in. stosowania dwujęzycznego nazewnictwa kaszubskich miejscowości, wprowadzania języka kaszubskiego jako języka pomocniczego do urzędów gmin, a także ujednolicenia systemu edukacji regionalnej (w tym nauki języka). Na podobne mechanizmy ochrony i rozwoju języka regionalnego - kaszubskiego - wskazuje również europejskie rozporządzenie. Obowiązująca w Polsce od 2009 roku Europejska karta języków regionalnych i mniejszościowych podkreśla istotność działań nakierowanych na promowanie języka danej grupy [Europejska..., 2009].

Oba dokumenty, pozostając spójne w swoich zapisach, dają Kaszubom solidną podstawę do językowej rewitalizacji. Trzeba jednak zwrócić uwagę, że chociaż rok 2005 był z punktu widzenia tej etnicznej wspólnoty przełomowy, jej historia pokazuje, że niezależnie od sytuacji dziejowej, język stanowił najbardziej wyróżniający element etnicznej odmienności Kaszubów. Zauważając tę zależność, kaszubskie elity stopniowo dążyły do przyznania rodzimej mowie należytego statusu. Aby z „gwary”, „dialektu” lub „gorszej polszczyzny” uczynić „język”, musiały jednak powstać sprzyjające warunki nie tylko polityczne, ale też społeczne (zmiana mentalności zarówno wśród samych Kaszubów, jak i osób spoza grupy). Dodatkowym wsparciem dla podjętych w tym celu działań miały być rozwinięte badania socjolingwistyczne oraz „osłabienie «problemu niemieckiego» na Pomorzu i możliwość odwołania do kontekstu europejskiego" [Obracht-Prondzyński, 2002: 326].

Początkiem dla tego procesu stały się przemiany ustrojowe w Polsce w latach osiemdziesiątych XX wieku. Rozpoczęte wówczas coraz śmielsze dyskusje o to czym jest i czym powinien być kaszubski (a co za tym idzie - kim właściwie są Kaszubi?) miały swoje zwieńczenie podczas zorganizowanej w październiku 1991 roku konferencji pt. „Problem statusu 
językowego kaszubszczyzny" [Dołowy-Rybińska, 2010: 64-65]. W jej trakcie dyskutowane były głównie dwie koncepcje - uznająca kaszubski za osobny język oraz druga, traktująca kaszubski jako język regionalny. Chociaż sama konferencja nie przyczyniła się w sposób bezpośredni do zmiany oficjalnego statusu kaszubskiego, wypracowała stanowisko, które usprawniło późniejszą procedurę instytucjonalną. Oficjalne uznanie kaszubskiej mowy za język regionalny spowodowało, że podmiotowość samych Kaszubów również opisywana jest od tej pory przez pryzmat przypisanego do nich języka.

Tożsamościowy wymiar języka kaszubskiego i jego - uznane również zewnętrznie - znaczenie dla zachowania kaszubskiej kultury powoduje, że język regionalny staje się podstawą wielu działań instytucjonalnych. Co jednak istotne, skutecznej realizacji kaszubskiego ożywienia językowego upatruje się już nie tylko w sferze instytucjonalno-prawnej, ale w wykorzystaniu jej możliwości w sferze prywatnej. Prowadzona w taki sposób polityka językowa stawia pytanie o wewnętrzne, symboliczne granice kaszubskiej społeczności. O to w jakim wymiarze uzasadnione jest mówienie o wspólnocie wartości etnicznych budowanych na wspólnym kodzie komunikacyjnym.

W dalszej części artykułu, podążając za narracją biorących udział w badaniu mieszkańców kaszubskiej gminy, postaramy się prześledzić jak w dobie szeroko pojętej globalizacji zachodzą przemiany etniczności w społeczności lokalnej. Jaki wpływ działania zewnętrzne mają na trwałość symbolicznych granic.

Podstawę analizy stanowią indywidualne wywiady pogłębione (IDI), realizowane od maja 2014 roku w kaszubskiej gminie wiejskiej Parchowo (powiat bytowski). W czasie cyklicznych wyjazdów badawczych (do października 2016) zgromadzono 50 IDI $^{1}$. Rozmówcy to mieszkańcy ośmiu gminnych miejscowości, osoby o zróżnicowanych statusach społecznych, zajmujące w parchowskiej społeczności rozmaite pozycje. Analiza materiału, wśród którego są wypowiedzi zarówno osób duchownych, lokalnych

Pierwsza część badania została zrealizowana w ramach projektu „Nazwy i granice etniczne. Problemy wprowadzania dwujęzycznych nazw w Polsce na podstawie ustawy o mniejszościach z roku 2005”. Praca nad badaniami została podjęta w toku zajęć akademickich, prowadzonych przez prof. Sławomira Łodzińskiego oraz mgr. Wojciecha Ogrodnika w Instytucie Socjologii UW, pt. „Dwujęzyczność w praktyce - języki mniejszości narodowych w społeczności lokalnej”. Badania terenowe zostały przeprowadzone wówczas przez dwanaścioro uczestników wspomnianych zajęć: Ewę Cichocką, Justynę Kanię, Annę Kokot, Monikę Mironiuk, Cezarego Niewiadomskiego, Malwinę Niewięgłowską, Zofię Penzę, Katarzynę Sierawską, Adriana Wróblewskiego, Katarzynę Żero oraz autorki niniejszej analizy, które samodzielnie realizowały kolejne wyjazdy badawcze. 
aktywistów, urzędników i pracowników szkół, ale również rolników, osób zajmujących się własnym gospodarstwem oraz drobnych przedsiębiorców i osób niepracujących pozwoliła uzyskać przekrój lokalnej społeczności. Wiek rozmówców jest zróżnicowany, najmłodsi badani mieli w momencie prowadzenia wywiadów około 25 lat, najstarsi około 80 lat.

Sama gmina Parchowo choć dziś znajduje się w centralnym miejscu Pomorza, w swojej przeszłości znajdowała się na polsko-niemieckim pograniczu, co bez wątpienia wpłynęło na przywiązanie do ojczyzny regionalnej (Kaszubszczyzny), a nie zmiennej narodowej (polskiej lub niemieckiej), [Borzyszkowski, 2005a]. Gmina Parchowo składa się z 11 sołectw, jest zamieszkiwana przez 3738 mieszkańców [www.gdansk.stat.gov.pl] ${ }^{2}$. Na stronie internetowej gminy można przeczytać, że jest to „kaszubska gmina o charakterze rolniczym”. Jest oddalona od ośrodków przemysłowych - co stanowi atut pod względem turystycznym czy ekologicznym, jednak przyczynia się do wysokiego wskaźnika bezrobocia lub konieczności dojazdów do miast. Ze względu na walory krajobrazu, w XIX wieku teren, zawierający gminę, został nazwany „Szwajcarią Kaszubską” [Borzyszkowski, 2005b].

O etniczności gminy nie świadczy jednak tylko geograficzne położenie. Gmina Parchowo, na mocy ustawy o mniejszościach z 2005 roku, jako pierwsza gmina $\mathrm{w}$ Polsce skorzystała $\mathrm{z}$ możliwości wprowadzenia języka regionalnego (kaszubskiego) do urzędu jako języka pomocniczego. Pięć lat później, czyli w 2011 roku na terenie gminy Parchowo ustawione zostały dwujęzyczne (polsko-kaszubskie) tablice z nazwami gminnych miejscowości [mniejszosci.narodowe.mswia.gov.pl].

Aktywność na polu instytucjonalnej etnicyzacji stanowiły przyczynek do sformułowania pierwszych pytań badawczych. Choć początkowo koncentrowały się one głównie na publicznym wymiarze etniczności w społeczności lokalnej, w toku badań rozmówcy wskazywali kolejne, istotne z ich punktu widzenia, obszary, w których kaszubskość się przejawia. W ten sposób możliwe było zredefiniowanie założeń badawczych i spojrzenie na materiał empiryczny z nowej perspektywy. Dzięki temu, podążając za narracją członków lokalnej społeczności, miałyśmy szansę przyjrzeć się wpływowi globalnych procesów społecznych na zachowanie najważniejszych, z punktu widzenia badanych, wartości - języka kaszubskiego i religii katolickiej. Ich udziału i wpływu na codzienne życie, wybory oraz postawy członków etnicznej wspólnoty.

2 Stan na 2016 rok. 


\section{Język kaszubski w sferze publicznej}

Obserwując sytuację i rozwój języka kaszubskiego w sferze publicznej można mówić o jego sukcesie. Decyduje o tym przede wszystkim postępująca etnicyzacja sfery publicznej. Do kluczowych elementów polityki językowej stosowanej wobec społeczności kaszubskiej należy zaliczyć uzyskanie oficjalnego statusu języka, co wpłynęło pozytywnie na ujednolicenie sytemu kaszubskiej edukacji szkolnej, a także umożliwiło używanie języka pomocniczego na szczeblu samorządowym oraz dało początek formalnemu, dwujęzycznemu nazewnictwu.

Zrealizowane w gminie Parchowo badanie wykazało, że dla rozmówców procesy te mają silne znaczenie symboliczne. Jak wyrażali to rozmówcy: to jest świadectwo na to, że ten kaszubski wychodzi z podziemia... [K1_02]. Podkreślali również fakt, że: No to jest chluba dla Kaszubów, że mamy język, bo to język, a nie gwara. Gwar jest dużo (...) a my mamy język[K2_04].

Istotność uznania wartości rdzennej grupy przez osoby spoza kaszubskiej wspólnoty etnicznej potwierdza konieczność działań polityki językowej. Poczucie „podziemności” języka, jego niższej wartości i braku stosowalności to tylko niektóre z przekonań, z którymi zmagają się działania rewitalizujące kaszubski. Uzyskanie statusu języka regionalnego i jednoznaczne sprecyzowanie wynikających z tego praw było jedynie przyczynkiem do językowego ożywienia kaszubszczyzny. To natomiast odbywać miało się na wielu płaszczyznach. Jedną z nich jest kaszubskojęzyczna edukacja szkolna.

Podstawowym elementem przekazywania języka kaszubskiego kolejnym pokoleniom użytkowników jest odpowiednia socjalizacja. Odpowiedzią na jej zanik w sferze prywatnej było przeniesienie jej do sfery publicznej przez ogólnie przyjęty program nauczania. Chociaż w historii Kaszubów kaszubskojęzyczne nauczanie było realizowane wcześniej (przeważnie z inicjatywy lokalnych aktywistów), po 2005 roku sprecyzowano i ujednolicono jego zasady. Włączenie języka kaszubskiego na listę przedmiotów maturalnych, a także utworzenie na Uniwersytecie Gdańskim kierunku umożliwiającego jego naukę na studiach wyższych symbolicznie zrównało statusy języka większościowego (polskiego) i regionalnego. W ten sposób, jak twierdzą badani, kaszubski nie jest już językiem, w którym: (...) sobie mówili dla siebie,.on jest też ważny dla kogoś innego [K2_22].

Podobne mechanizmy zadziałały w przypadku wizualnej obecności języka. Po wprowadzeniu ustawy o mniejszościach polsko-kaszubskie nazewnictwo miejscowości na stałe wpisało się w przestrzeń Kaszubszczyzny, tworząc swoisty krajobraz kulturowy (językowy). Etnicyzacja przestrzeni 
w symboliczny sposób zrównuje grupę odrębną kulturowo (Kaszubów) z większością społeczeństwa (w skali kraju - osoby bez kaszubskich korzeni etnicznych). Dodatkowym wzmocnieniem tego procesu jest możliwość stosowalności języka grupy przed organami gminy, o ile dany samorząd zdecydował się na wprowadzenie go jako języka pomocniczego.

Trudno zaprzeczyć, że tego rodzaju działania podnoszą rangę kaszubskiego. Akcentowanie jego stosowalności w rozmaitych sferach życia na nowo wyznacza obszary etnicznej manifestacji. Urzędy i szkoły to - obok kościołów parafialnych - miejsca znaczące, wyróżniające się wysokim prestiżem wśród lokalnych społeczności. Przyglądając się dzisiejszej sytuacji na Kaszubach można zaobserwować znaczący zwrot ku kaszubskości. Wprowadzenie języka kaszubskiego do sfery publicznej, która przez wiele lat była dla kaszubskiej etniczności niedostępna, m.in. w okresie PRL-u [Obracht-Prondzyński 2002], można uznać za znaczące osiągnięcie. To, co w lokalnej pamięci traktowane było w kategoriach prywatnych, od ponad 10 lat jest przedmiotem życia publicznego nie tylko lokalnie. Publiczny wymiar kaszubskości, chociaż w znaczący sposób warunkowany jest kontekstem instytucjonalno-prawnym, w największym stopniu zależy od samych członków etnicznej wspólnoty. Ci natomiast mają dziś do dyspozycji wachlarz możliwości, wspierający rozwój języka kaszubskiego i pozwalający na włączanie języka grupy do codziennej komunikacji. Obok klasycznych dzieł na stałe wpisanych w kaszubską kulturę (m.in. twórczość Aleksandra Majkowskiego) warto zwrócić uwagę chociażby na liczne witryny internetowe prowadzone w języku kaszubskim, ale też specjalne aplikacje umożliwiające przetłumaczenie popularnych serwisów właśnie na ten język regionalny (m.in. Facebook, Wikipedia).

W przypadku społeczności kaszubskiej „aktualizowanie” etniczności odbywa się przez działania nakierowane na promocję języka grupy - jej wartości rdzennej. Pytaniem otwartym pozostaje jednak funkcjonalność tych działań w świetle spadającej używalności języka grupy ${ }^{3}$. Przeprowadzone w Parchowie badanie wykazało również silne przekonanie o nieużyteczności języka grupy, co powoduje jego nieatrakcyjność wśród młodych osób żyjących na terenie Kaszub. Obserwowalne dziś próby odwrócenia niekorzystnych procesów globalizacyjnych (unifikacja kulturowa, fragmen-

\footnotetext{
Warto zauważyć, że w ostatnim Narodowym Spisie Powszechnym z 2011 roku kaszubskich deklaracji tożsamościowych (w sumie - zarówno wyłącznie kaszubskich, jak i współwystępujących z innymi) było 232 547, podczas gdy kaszubskich deklaracji językowych (w sumie - zarówno w znaczeniu języka domowego, jak i ojczystego) było 121 939. Oznacza to, że identyfikacji tożsamościowych było prawie dwukrotnie więcej, niż językowych [www.stat.gov.pl].
} 
taryzacja tożsamości, wysoki prestiż języków międzynarodowej komunikacji) przyczyniających się do zanikania języków mniejszości, w przypadku społeczności kaszubskiej odbywają się właśnie z wykorzystaniem możliwości, jakie globalizacja stwarza (media, popkultura). Czy taki uniwersalny schemat zachowania wartości grupy sprawdza się w przypadku Kaszubów? Rozważając tę kwestię należałoby postawić dodatkowe pytanie o relację, $\mathrm{w}$ jakiej pozostaje on $\mathrm{z}$ wartościami grupy. Te natomiast, jak wykazują badania kaszuboznawcze, koncentrują się wokół sfery domowo-sąsiedzkiej, w której szczególne miejsce zajmuje religia.

\section{Język kaszubski w działalności Kościoła}

Na sytuację języka kaszubskiego możemy patrzeć dwojako - z perspektywy instytucjonalnej, czyli planowanych działań na rzecz języka regionalnego, ale również z perspektywy aksjologicznej, gdzie o Kaszubszczyźnie mówi się jako „ikonie kaszubskości i rytualnym wyzwalaczu tożsamości etnicznej" [Mazurek, 2009: 93]. Z punktu widzenia społeczności lokalnej, instytucją łączącą oba te wymiary jest Kościól. W przeciwieństwie do instytucji państwowych, jakimi są szkoły i urzędy, w działalności lokalnych parafii język kaszubski nie jest jednak silnie promowany.

Wspólnotowe formy życia religijnego są bardzo istotne dla trwania i rozwoju kultury regionu. Badania kaszuboznawcze wskazują, że liczne formy religijności wytworzone na tym obszarze są silnie związane z tożsamością etniczną i stanowią swoisty etos grupy kaszubskiej. Z badań Brunona Synaka [1998: 105-112] wynika, że to właśnie „religijność” jest fundamentem budującym autostereotyp Kaszubów, z którego wynikają „kaszubskie wartości”, takie jak pielęgnowanie własnego języka [Obracht-Prondzyński, 2012: 20], pracowitość, gospodarność, wartości rodzinne, przywiązanie do genealogii, jak również do miejsca zamieszkania i krajobrazu.

Zestawiając kaszubskie przywiązanie do życia religijnego z dużym znaczeniem języka grupy, nie dziwią próby jego włączania w obrzędy religijne. Nie jest to zjawisko nowe i związane wyłącznie $\mathrm{z}$,poustawową rzeczywistością”, jednak trudno precyzyjnie wskazać na początki języka kaszubskiego w Kościele katolickim. Najistotniejszą z punktu widzenia dzisiejszego użycia kaszubszczyzny w liturgii, jest powojenna działalność księdza Franciszka Gruczy, który starał się włączyć ten język w obrządek. Jednak mimo grona zwolenników wśród kaszubskich duchownych, brak poparcia tej inicjatywy przez biskupstwo pelplińskie sprawił, że język kaszubski do życia 
religijnego wszedł w formie pieśni i czytań ${ }^{4}$, a nie stał się językiem liturgii [Dołowy-Rybińska, 2011: 477-478].

Jak zauważa Nicole Dołowy-Rybińska, początkowa niechęć do obecności języka kaszubskiego w liturgii nie była wyłącznie cechą kleru, również wierni traktowali ją jako nienaturalną. Ponadto, argumentacja duchowieństwa, na rzecz utrzymania wyłącznie języka polskiego w liturgii, była budowana na przeświadczeniu, że elementy mszy w kaszubszczyźnie nie będą zrozumiałe dla wszystkich wiernych (nawet tych pochodzenia kaszubskiego). Obecnie w kilkunastu parafiach na terenie Kaszub można spotkać się z nabożeństwami w języku kaszubskim ( $\mathrm{z}$ dość dużym zróżnicowaniem częstotliwości: od jednej w miesiącu do jednej w roku). Zdaniem lokalnych aktywistów, taki stan rzeczy wymaga poprawy, ponieważ nie spełnia potrzeb wiernych [Dołowy-Rybińska, 2011: 479].

O ile włączenie kaszubszczyzny w liturgię (na szerszą skalę) jest bardzo trudnym zadaniem, o tyle nie wolno pominąć kluczowych sukcesów na polu nobilitacji języka kaszubskiego w życiu religijnym. Jednym z przełomowych wydarzeń na tym gruncie była wizyta Jana Pawła II w 1997, który apelował do Kaszubów o szczególną dbałość o wartości i tradycje wpisane w kaszubską tożsamość. Jego słowa wpłynęły na działania włączające kulturę i język w życie religijne, czego najbardziej wyrazistym przykładem była pielgrzymka do Jerozolimy w 2000 roku, podczas której odsłonięto tablice z kaszubskim przekładem modlitwy „Ojcze nasz” [Dołowy-Rybińska, 2011: 481].

Warto w tym miejscu zauważyć, że zapotrzebowanie na msze w języku kaszubskim jest bardzo silnie zróżnicowane (w zależności od regionu Kaszub). Mimo to, podczas uroczystości skupiających Kaszubów z całego Pomorza, podkreśla się etniczny wymiar religijności oraz specyfikę kultury kaszubskiej. Tym samym, w regionie Kaszub możemy obserwować zjawisko próby podnoszenia rangi języka kaszubskiego przez włączanie go w życie religijne - nobilitację jednej wartości etnicznej (języka) przez inną wartość grupy (religię).

\section{„Bòże pòmagéj” - lokalny wymiar religijności}

Na uwagę zasługuje bardzo silne akcentowanie wśród rozmówców istotności wiary i Kościoła dla całej społeczności lokalnej. Deklaracje przywiązania do sfery religijnej w pewnej mierze są potwierdzeniem wspominanych

4 Pierwsze przekłady Pisma Świętego na język kaszubski datuje się na XVI wiek. 
przez nas badań Brunona Synaka. Mieszkańcy gminy podkreślali obecność religii $\mathrm{w}$ życiu codziennym, ale co szczególnie istotne $\mathrm{z}$ punktu widzenia rewitalizacji języka, ta religijność wyrażała się również w obszarze komunikacji domowo-sąsiedzkiej. Badani podkreślali, że obecność religijnych pozdrowień świadczy o dużym znaczeniu religii w życiu Kaszubów: religia to jest myślę pierwsze, wchodzi się do domu i mówi 'Niech będzie pochwalony Jezus Chrystus', wychodzi 'Zostańcie z Bogiem' [K2_24]. Co ciekawe, są to zwroty głównie zarezerwowane dla „swoich” i często występują w języku kaszubskim: Jak ktoś jest $w$ ogrodzie, coś tam robi to jest to takie kultywowane u nas, to „Szczęść Boże! (...) „Bòże pòmagéj” tak jest no, po kaszubsku [K2_14].

O ile obecność języka kaszubskiego w religijnych pozdrowieniach i codziennych zwrotach jest realna, o tyle jego obecność w liturgii już jest pewnym wyobrażeniem. Niektórzy mieszkańcy gminy byli przekonani, że w pobliskich parafiach odprawia się msze po kaszubsku regularnie. Niekiedy nawet wskazywali konkretny kościół z kaszubską liturgią, ale było to dementowane przez lokalnych księży. Warto zastanowić się z czego wynika ten rozdźwięk między stanem rzeczywistym a domniemywaniem społeczności lokalnej. Jedną z przyczyn takiego sytuacji może być niewątpliwy sukces języka kaszubskiego w sferze publicznej, przy jednoczesnym braku zakorzenienia kaszubskiej liturgii w tradycji regionu. Odkąd język kaszubski zyskał prawny status języka regionalnego, kaszubskie organizacje podejmowały szereg działań, by podnieść jego status, co zostało szczegółowo opisane w pierwszych częściach artykułu.

Choć dziś panuje powszechna zgoda, że język kaszubski jest wartością istotną dla całej grupy regionalnej, to rzeczywiste jej postrzeganie wciąż bywa obciążane skojarzeniami z niższymi i niewykształconymi warstwami społecznymi. Za przejaw takiego postrzegania języka kaszubskiego można traktować argumentację jednego z proboszczów, który tłumaczył dlaczego na terenie gminy Parchowo nie odprawia się mszy w języku kaszubskim. Nasz rozmówca odwoływał się do konieczności dostojeństwa słowa w liturgii, a bez znajomości oficjalnej, standaryzowanej wersji języka tej dostojności nie można osiągnąć. Jak mówił: kaszubski nadaje się do obory, ale nie do ołtarza [K2_19]. W dalszej jego narracji pojawiła się jednak silna negacja, jakoby język kaszubski miał negatywne konotacje, odwołujące się do jego wiejskiego pochodzenia. Z czego więc wynika ta rozbieżność między spontanicznym a oficjalnym postrzeganiem kaszubskiego? Po pierwsze, mowa tu o języku kaszubskim rozumianym dwojako: jako dawnym, komunikacyjnie użytecznym, choć dziś zanikającym i silnie zróżnicowanym wewnętrznie 
etnolekcie oraz nowym, wypromowanym na mocy unijnej konwencji, zestandaryzowanym i urzędowym „języku regionalnym”. Po drugie, na język liturgii wpłynęła zasadniczo historia badanego obszaru, który był terenem polsko-niemieckiego pogranicza. Tradycyjne zakorzenienie liturgii w języku polskim wiązało się z próbami obrony tożsamości podczas Kulturkampfu. Pomorski kler wypracował wówczas sposoby przeciwdziałania germanizacji, co utrwaliło się w pamięci społecznej: „I ten język polski wchodził do nas tak bardzo stopniowo. Księża, no kazania były po polsku, chociaż w czasach Kulturkampfu, był zakaz głoszenia kazań po polsku, ale księża się z tego wymigiwali" [K2_19].

Nieliczne próby prowadzenia mszy po kaszubsku ${ }^{5}$ stanowią dla mieszkańców gminy Parchowo rodzaj ciekawostki, która zaburza tradycyjny obraz nabożeństwa. W ich świadomości wizerunek księdza łączył się z lepszym wykształceniem, a tym samym posługiwaniem się językiem urzędowym. Jeden z naszych rozmówców podkreślając, że msza kaszubska nie jest elementem tradycji mówił: „Jest to jakaś nowość, jest to jakaś ciekawostka, ale nie jest to coś co było zakorzenione. Chociaż ludzie mówili wszyscy po kaszubsku, mówię o starych dziejach, ale msza była zawsze po polsku. (...)było tak przyjęte, że msza jako coś uroczystego była w języku polskim, ksiądz był zawsze wykształcony i używał języka, który był do tej obrzędowości przypisany” [K2_22]. Język polski zdaje się nie tracić pozycji „języka sacrum" niezależne od mocy komunikacyjnej języka kaszubskiego. Innymi słowy, nawet jeżeli język kaszubski byłby powszechnie znany i używany na co dzień, to prawdopodobnie językiem modlitwy pozostanie polski. Jedna z badanych, choć jej językiem domowym był kaszubski, mówiąc o kaszubskich modlitwach, negowała ich użyteczność: „Nawet są modlitwy po kaszubsku, chociaż no dla mnie te modlitwy też są właśnie takie obce, (...), nawet moja mama mówiąc po kaszubsku, kiedy na przykład klękaliśmy do pacierza, to było po polsku" [K1_02].

Przeprowadzone badanie wykazało, że tym, co wspólne dla języka kaszubskiego i praktyk religijnych członków kaszubskiej społeczności, pozostają jedynie spontaniczne, sąsiedzkie pozdrowienia (wspomniane „Zostańcie z Bogiem”) oraz nieliczne pieśni religijne autorstwa kaszubskich twórców. Kościól, mimo że reprezentuje wartości utrwalone w etosie kaszubskiej wspólnoty, pozostaje instytucją odporną na promocję języka kaszubskiego. Mimo to w obrzędowość włączane są elementy świadczące

\footnotetext{
Sporadycznie, przy większych uroczystościach są zapraszani księża spoza parafii, którzy wplatają w niektóre części nabożeństwa język kaszubski.
} 
o kaszubskości regionu (kaszubska ornamentyka w wystroju ołtarzy, śpiewy, kaszubskie stroje ludowe), jednak nie przenikają one do tradycji religijnej podtrzymywanej na Kaszubach. W tym sensie potencjał Kościoła pozostaje niewykorzystanym polem promocji języka etnicznego.

\section{Podsumowanie}

W globalnych procesach, w których etniczność coraz częściej ulega rozmyciu, przypadek Kaszubów wydaje się być szczególnie interesujący. Kaszubi, jako jedyna w Polsce społeczność posługująca się językiem regionalnym, stanowią „unaocznienie”/przykład rozdźwięku między instytucjonalnym sukcesem języka a codziennymi praktykami językowymi. Niestety w dobie hegemonii języka angielskiego, dbanie o wartość rdzenną - język regionalny, kłóci się z interesem indywidualnym członków tej społeczności etnicznej. Kładąc nacisk na naukę języków nowożytnych (angielski, niemiecki, francuski i inne), Kaszubi nie negują i nie odrzucają swojego dziedzictwa językowego. Zatracona naturalna transmisja międzypokoleniowa języka, skutkuje sytuacją, w której nauka „rodzimej mowy”, staje się kolejnym wyzwaniem - angażującym i czasochłonnym „projektem”.

Podjęta analiza skupiła się na zarysowaniu wpływu lokalnych instytucji oraz organizacji na społeczne funkcjonowanie języka regionalnego. Jak pokazał materiał empiryczny zebrany w gminie Parchowo, takie instytucje jak urzędy, szkoły czy Kościoły wydają się naturalną przestrzenią do promowania i podnoszenia rangi języka regionalnego. Potencjał tych miejsc jest jednak wykorzystywany w różny sposób. Odgórne działania nie zawsze mają moc oddziaływania na codzienne praktyki językowe społeczności lokalnej. Pytaniem pozostaje, na ile dzisiejsze funkcjonowanie języka kaszubskiego w sferze publicznej wynika z realnych potrzeb członków społeczności lokalnej, a na ile jest procesem wykreowanym, „etniczną inscenizacją”. To implikuje kolejną wątpliwość - czy tego rodzaju „etniczna inscenizacja” jest czymś niekorzystnym z punktu widzenia grupy etnicznej. Nawet jeśli język kaszubski straci swoją funkcję komunikacyjną, wymiar symboliczny może pozostać dla grupy wartością wystarczającą. Jak pokazuje przeprowadzone badanie, publiczne mówienie o używalności języka kaszubskiego, wzmacnia tożsamość regionalną i zapewnia poczucie etnicznej dumy. 


\section{Bibliografia}

Appadurai A. (2005), Nowoczesność bez granic. Kulturowe wymiary globalizacji, Kraków.

Barth F. (2004), Grupy i granice etniczne: społeczna organizacja różnic kulturowych, [w:] Badanie kultury. Elementy teorii antropologicznej. Kontynuacje, (red.) M. Kempny, E. Nowicka, Warszawa.

Bednarek A. (2015), Religijność a tożsamość kaszubska na przykładzie młodych Kaszubów. Zarys zagadnienia $w$ świetle literatury $i$ wstępnych badań antropologicznych, „Etnografia. Praktyki, Teorie, Doświadczenia”, nr 1.

Borzyszkowski J. (2005a), Antropologia Kaszub i Pomorza. Badania - Kultura - Życie codzienne, Gdańsk.

Borzyszkowski J. (2005b), Mòdrô Kraina. Dzieje i współczesność gminy Parchowo, Gdańsk - Parchowo.

Borzyszkowski J. (2000), Z dziejów Kościoła katolickiego na Kaszubach i Pomorzu w XIX i XX wieku, Gdańsk-Pelplin.

Comaroff J.L., Comaroff J. (2011), Etniczność sp z o.o., Kraków.

Dołowy-Rybińska N. (2010), Kaszubi z Pomorza, Gdynia.

Dołowy-Rybińska N. (2011), Języki i kultury mniejszościowe w Europie: Bretończycy, Łużyczanie i Kaszubi, Warszawa.

Edensor T. (2004), Tożsamość narodowa, kultura popularna i życie codzienne, Kraków.

Europejska Karta Języków Regionalnych i Mniejszościowych, Dz. U. 2009, nr 137, poz. 1121.

Giddens A. (2010), Nowoczesność i tożsamość. „Ja” w epoce późnej nowoczesności, Warszawa.

Godlewska E. (2014), Prawa językowe mniejszości narodowych - problem $w$ realizacji, [w:] Sakson A. (red.), Mniejszości narodowe i etniczne w Polsce i Europie. Aspekty politycznei społeczne, Toruń.

Kymlicka W. (2012), Multiculturalism: Success, Failure and the Future, Washington.

Łodziński S. (2007), Między grupa etniczną a społecznościa posługująca się językiem regionalnym. Ewolucja statusu prawnego Kaszubów w polityce państwa w Polsce po 1989 roku [w:] Kim sa Kaszubi? Nowe tendencje w badaniach społecznych, (red.) C. Obracht-Prondzyński, Gdańsk.

Makrut H. (2007), Stan i problemy dzisiejszego języka kaszubskiego, „Biuletyn Rady Języka Kaszubskiego".

Mazurek M. (2009), Język jako wyznacznik tożsamości kaszubskiej, [w:] Kulturowa odmienność w działaniu. Kultury i narody bez państwa, (red.) E. Nowicka, Kraków.

Mazurek M. (2010), Język, przestrzeń, pochodzenie. Analiza tożsamości kaszubskiej, Gdańsk.

Obracht-Prondzyński C. (2012), Dylematy Związane z kaszubską tożsamością, [w:] Społeczność kaszubska w procesie przemian, Kultura - Tożsamość - Język, (red.) K. Kleina, C. Obracht-Prondzyński, z. 12, Warszawa. 
Obracht-Prondzyński C. (2002), Kaszubi. Między dyskryminacją a regionalna podmiotowością, Gdańsk.

Perszon J. (2011), Kultura religijna jako element tożsamości Kaszubów, [w:] Wielkie Pomorze. Tożsamość i wielokulturowość, (red.) A. Kuik-Kalinowska, D. Kalinowski, Gdańsk - Słupsk.

Sapir E. (1978), Kultura, język, osobowość. Wybrane eseje, Warszawa.

Smolicz J. (1987), Język jako wartość rdzenna, „Kultura i Społeczeństwo”, nr 1.

Synak B. (1998), Kaszubska tożsamość. Ciagłość i zmiana, Gdańsk.

Ustawa z dnia 6 stycznia 2005 r. o mniejszościach narodowych i etnicznych oraz o języku regionalnym, Dz. U. $2005 \mathrm{nr} 17$ poz. 142.

Wicherkiewicz T. (2007), Tożsamość etniczna a język regionalny na przykładzie dolnoniemieckiego i limburskiego, [w:] Kim sa Kaszubi? Nowe tendencje $w$ badaniach społecznych, (red.) C. Obracht-Prondzyński, Gdańsk.

\section{Strony internetowe}

Statystyczne Vademecum Samorządowca, Urząd Statystyczny w Gdańsku, gdansk.stat.gov. pl, [25.11.2017].

Urzędowy rejestr gmin, w których używany jest język pomocniczy, mniejszosci.narodowe. mswia.gov.pl, [25.11.2017].

Rejestr gmin, na których obszarze używane są nazwy w języku mniejszości, mniejszosci. narodowe.mswia.gov.pl, [25.11.2017].

Ludność według języka ojczystego, płci oraz charakteru miejsca zamieszkania w 2011 roku [w:] Wybrane tablice dotyczące przynależności narodowo-etnicznej, języka i.wyznania - NSP 2011, www. stat.gov.pl, [25.11.2017].

\section{SUMMARY}

Language, values, boundaries. Ethnic language revitalisation in the age of globalisation - the situation of Kashubian community

The European policies regarding minorities include a number of institutionalised practices aiming to protect ethnic languages. When it comes to Poland, these procedures are particularly significant in the case of Kashubians, who are the only group in the country having a.status of "a.community using a regional language". These legal circumstances justify considering the significance of Kashubian language for the members of ethnic community and its relations to other key values of the group.

Analysis presented in the paper confronts the above matters with the results of the qualitative field research conducted in the Kashubian municipality of Parchowo. The analysis focused on the influence of particular institutions (educational, administrative, church) on the process of Kashubian language revitalisation from the point of view of the 
local community. Research material suggested that maintaining cultural distinctiveness and regional language is a.challenge for Kashubians, especially in the age of unification and globalisation processes.

KEYWORDS: Kashubians, ethnic minority, ethnicization of religion, regional language, language revitalisation 